\title{
What Is Gratitude? Ingratitude Provides the Answer
}

\author{
Jessica L. Navarro Jonathan R.H. Tudge \\ University of North Carolina Greensboro, Greensboro, NC, USA
}

\section{Keywords \\ Gratitude $\cdot$ Ingratitude $\cdot$ Virtue $\cdot$ Appreciation $\cdot$ Moral obligation}

\begin{abstract}
Current scholarship on "gratitude" has largely ignored its opposite - ingratitude. As a result, gratitude is no longer distinguishable from constructs such as appreciation and happiness. This was not the case over previous centuries - ingratitude was viewed as something monstrous, a failure to reciprocate would loosen the bonds holding society together. The opposite, gratitude, was seen as a virtue. Reciprocity has come under attack because "obligation" has been understood in only one of two possible senses. The first relates to contracts and justice - one has a heteronomous obligation to pay off a debt or fulfill a contract. The second is a sense of obligation that comes from within, autonomously - the desire to help those that have helped us. Here, we argue, is where gratitude and ingratitude are situated. This view has two important consequences; one relates to the measurement of gratitude and the other to raising youth to be grateful people.

(C) 2020 The Author(s)

Published by S. Karger AG, Basel
\end{abstract}

What is gratitude? As we shall show in this paper, most contemporary scholars writing about gratitude do not define it as a virtue, and the scales that are most commonly used to measure this construct do not assess anything virtuous. By contrast, we think that gratitude is a virtue and that what most scholars define as "gratitude" would be better thought of as "appreciation" (Adler \& Fagley, 2005; Fagley, 2016; Tudge \& Freitas, 2018). To understand our reasoning, it is necessary to explain what is meant by calling gratitude a virtue and why ingratitude is considered its opposite - a vice.

We take virtue to refer to something related to one's character that is "morally praiseworthy" (Kristjánsson, 2013) or a habitual character trait that "disposes agents to act in morally optimal ways" (Carr, Morgan, \& Gulliford, 2015). A virtue has some intrinsic value - one acts that way because it is the right thing to do, and not because it will lead to some extrinsic reward. One might feel good as a result of acting morally, but it is not a moral action if it is performed for the instrumental purpose of feeling good. It is, we will argue, the willingness to take on an obligation to reciprocate to our benefactors, without thinking that we will gain something as a result, which is the essence of gratitude as a moral virtue. By contrast, a positive emotion on being given a gift, or appreciation for the pleasant things that happen to us, or the happy recognition that we have access to the good things of life may well make us feel happy, but seem to have nothing to do with morality. Taking the position that gratitude qualifies as a moral virtue makes even more sense when considering that ingratitude is viewed as a heinous moral vice. karger@karger.com www.karger.com/hde

Karger $\stackrel{\text { ' }}{=}$

BOPEN ACCESS
(C) 2020 The Author(s)

Published by S. Karger AG, Basel

This is an Open Access article licensed under the Creative Commons Attribution-NonCommercial-4.0 International License (CC BY-NC) (http://www.karger.com/Services/OpenAccessLicense), applicable to the online version of the article only. Usage and distribution for commercial purposes requires written permission.
Jessica L. Navarro

Human Development and Family Studies

University of North Carolina Greensboro, 312 College Avenue, 248 Stone Building Greensboro, NC 27455 (USA)

jlnavarr@uncg.edu 
As supporting evidence for this view, one can find numerous statements from the giants of both literature and philosophy. Using a computer search engine to enter "ingratitude quotes" reveals the following: in Shakespeare's Twelfth Night, Viola states: "I hate ingratitude more in a man Than lying, vainness, babbling, drunkenness, Or any taint of vice." Cervantes described similar sentiments in Don Quixote: "The wicked are always ungrateful." Kant described ingratitude as "... the essence of vileness and wickedness," while Aquinas wrote that it "...is a special sin." Perhaps Bernard of Clairvaux described ingratitude most floridly: "Ingratitude is a burning wind that dries up the source of love, the dew of mercy, the streams of grace." Moving from search engines, and somewhat more prosaically, Baumgarten-Tramer noted: "Ungrateful persons are considered as thoroughly objectionable" (1938, p. 56). More recently, Watkins, Woodward, Stone, and Kolts (2003) noted: "In a recent study of over 800 descriptive trait words ... 'ungrateful' was rated as one of the most negative traits" (p. 432), Carr et al. (2015) wrote that it involved "a vicious deficit of gratitude" (p. 773), and Emmons (2016a) termed ingratitude "the king of the vices" (p. 141).

But why is ingratitude viewed as being so bad? Given the way in which most contemporary scholars and popular writers have treated gratitude, there would seem to be little reason to castigate those who exemplify its opposite. Since the turn of this century there has been a good deal of interest expressed in gratitude, with a number of scholarly books appearing (e.g., Emmons \& McCullough, 2004; Watkins, 2014; Carr, 2016; Tudge \& Freitas, 2018) as well as those intended for a lay audience (e.g., Emmons, 2007, 2013, 2016b; Froh \& Bono, 2014). In addition, countless articles, blog posts and podcasts devoted to inculcating and practicing gratitude have become mainstream. And yet there is surprisingly little consistency in what is meant by gratitude, even among scholars. There is certainly no agreement that it constitutes a virtue.

\section{The Meanings of Gratitude}

Gratitude has been called "a multi-layered concept that defies easy description or analysis" (Emmons, 2004, p. 10). For example, Emmons and Crumpler (2000) noted: "Gratitude has been conceptualized as an emotion, a virtue, a moral sentiment, a motive, a coping response, a skill, and an attitude" (p. 56). Wood, Froh, and Geraghty (2010), drawing on previous research by Wood, Maltby, Gillett, Linley, and Joseph (2008), established a "wider conceptualization of gratitude" (p. 891) and argued that gratitude encompasses eight different aspects: (a) individual differences in the experience of grateful affect, (b) appreciation of other people, (c) a focus on what the person has, (d) feelings of awe when encountering beauty, (e) behaviors to express gratitude, (f) appreciation rising from understanding life is short, (g) a focus on the positive in the present moment, and (h) positive social comparisons. For Watkins, Grimm, and Kolts (2004) "three aspects characterize dispositional gratitude: an appreciation for others, an appreciation for simple pleasures, and a sense of abundance" (p. 53). These examples illustrate some of the varied conceptualizations of gratitude employed by contemporary psychologists.

However, when viewed from the perspective of ingratitude, these wide-ranging approaches become problematic. If they all can be thought of as evidence of gratitude, does this mean that failure to experience them is evidence of ingratitude? For example, when people fail to have feelings of awe or a grateful affect upon encountering a beautiful sunset, do we castigate them as ungrateful? Most likely not. Ingratitude hardly qualifies as a "vicious deficit" or "one of the most negative traits" if it merely involves ambivalence about beauty or not being present in the moment. A historical review of how people have considered gratitude helps to shed light on this differentiation between gratitude as a virtue and its "wider conceptualization."

\section{Gratitude in Historical Perspective}

Gratitude has been written about throughout history, even in ancient times. In his treatise on the history of gratitude, Leithart (2014) described how members of the Athenian democracy, wishing to bring an end to corrupt oligarchies, attempted to separate gratitude from transactional exchanges. Rather than gratitude being an obligation between an individual patron or master and their workers or slaves, Athenians reimagined gratitude as a macroconstruct involving a "...circle of reciprocity to political leaders and the people” (p. 33).

Aristotle did not list gratitude as one of the virtues in Nichomachean Ethics (4th century BC/2014), but it is clear from other writings that he considered it highly. In Rhetoric (350 BC/2018), he contrasted written laws with "conduct that springs from exceptional goodness" which he praised. The examples he gave were "gratitude to, or requital of, our benefactors, readiness to help our friends, and the like ... This is what we call equity; people regard 
it as just; it is, in fact the sort of justice that goes beyond the written law" (book 1, chapter 13, p. 36). The use of the term "requital of" benefactors means that Aristotle considered gratitude more than simply an emotion (Konstan, 2016), as was true of his position on all virtues - without relevant action they did not qualify as a virtue (Annas, 2011; Kristjánsson, 2007).

At least one Roman philosopher also attempted to delineate the differences among gratitude, justice, and obligation. Seneca wrote:

A proof that gratitude is desirable for itself lies in the fact that ingratitude is to be avoided for itself, because no vice more powerfully renders asunder and destroys the union of the human race. To what do we trust for safety, if not in mutual good offices, one to another? (Seneca, $54 \mathrm{AD} / 2011$, p. 160)

Seneca held that gratitude is comprised of three interacting components: the benefactor, the benefit, and the beneficiary. For Seneca, intentions distinguish between contractual transactions (i.e., in a marketplace) and gratitude. For example, without benevolent and autonomous intentions on the part of both benefactors and beneficiaries no gratitude is necessary. Aristotle $(350 \mathrm{BC} / 2018)$ had made a similar point: "We owe no gratitude to such as were constrained to do the good they did us" (book 2, chapter 23, p. 72). However, for most Romans, gratitude continued to function as part of the unbalanced transactional relationship between patrons and their beneficiaries (Brown, 2012; Leithart, 2014).

The position taken by early Christians on giving and gratitude was a radical departure from the Romans (Brown, 2012). To the Romans, early Christians were ungrateful: "They look like ingrates because their gratitude is so big, so indiscriminate, that it confuses and destroys normal expectations about giving and receiving" (Leithart, 2014, p. 77). Instead of a circular reciprocity between benefactor and beneficiary, the Christian Church opined that gratitude was only owed to God, creating an "infinite circle" of gratitude; gratitude for all things must be expressed to God, because they ultimately come from God (Leithart, 2014). Rather than

...becoming indebted to the human benefactor ... I can simultaneously be grateful (to God) and ungrateful (rejecting enslaving bonds). At the same time, horizontal relations of need and dependency remain in place. Though my gratitude goes "over the head" of the human person, I am grateful for him, for his gifts and services, and I can acknowledge that I am dependent on him insofar as God has gifted him to gift me. (Leithart, 2014, p. 227, italics added)
Although Leithart did not make this point, the italicized phrase supports Winter's (1988) assertion that gratitude to human benefactors was viewed by early Christians not as Seneca had - as an intrinsic motivation - but more as an obligation that one was forced to honor.

By the Middle Ages gratitude had morphed into commercialized transactions; gratitude to God could be expressed by providing funds to benefit churches and other places of worship or by helping to fund "holy" wars. However, the Protestant reformation challenged this archetype of gratitude; gratitude was reframed back to a focus on Christ and God: "...there is a return for the gift of the body and blood of Christ ... It is not a return of things, but a self-offering in thanksgiving" (Leithart, 2014, p. 103). Philosophers and writers of the Renaissance reflected this rejection of transactional and commercialized gratitude, and instead began to reframe gratitude as a mechanism of social and moral virtue, whereas ingratitude was viewed as the "solvent of [social] bonds" and "an assault on flourishing human life" (Leithart, 2014, p. 113; see also Dunn, 1946).

From the seventeenth century, political theorists again wrote about gratitude in ways that echoed both Aristotle and Seneca. Thomas Hobbes (1651/2018) explicitly contrasted justice, linked to "antecedent covenant," and gratitude ("the fourth law of nature"), which was tied to "antecedent free-gift" (p. 139). The latter leads to benevolence, trust, and mutual help. Failure to engage in activities leading to the latter is explicitly termed "ingratitude" (p. 140). John Locke (1690) attempted to separate gratitude ("a readiness to acknowledge and return kindness received") from political discourse and relegate it to social and familial interactions (p. 456). This perspective gave rise to a "private and sentimental" form of gratitude (Leithart, 2014, p. 143), while viewing ingratitude (to the government) as a source of revolution and political unrest.

Adam Smith (1759/2000) wrote at length about gratitude in The Theory of Moral Sentiments, taking a secular perspective that was removed from theological philosophy. He viewed gratitude as an integral part of human existence: when "assistance is reciprocally afforded from love, from gratitude, from friendship, and esteem, the society flourishes and is happy" (p. 103). As had Aristotle and Seneca before him, Smith (1759/2000) contrasted the formal rights and obligations of justice and written laws with the informal duties of gratitude:

The man who does not recompense his benefactor, when he has it in his power, and when his benefactor needs his assistance, is, no doubt, guilty of the blackest ingratitude... [However] to oblige him 
by force to perform what in gratitude he ought to perform ... would, if possible, be still more improper than his neglecting to perform it. (pp. 95-96)

Similarly, although the contractual requirements of justice require precision in the rule of recompense (what, how much, and when), the informal obligations of gratitude permit no such precision.

Kant's approach to morality was deontological, focusing on rights and duties (Cureton \& Hill, 2015). Although Kant's approach to virtue was different from that of Aristotle, one similarity was the distinction he drew between heteronomous and autonomous duties and obligations. The former are linked with justice and have the force of law behind them - they have to be carried out or satisfied. The latter do not have such a force; they are autonomous in nature rather than heteronomous. In this case it is better to talk about the feeling of obligation (i.e., it comes from within) rather than something that is heteronomously imposed.

Georg Simmel (1908/1950) used the same distinction between contracts that are legally binding and gratitude, which "establishes the bond of interaction, of the reciprocity of service and return service, even when they are not guaranteed by external coercion" (p. 387). Unlike in the case of legal contracts, gratitude constitutes "the motive which, for inner reasons, effects the return of an inner benefit where there is no external necessity for it" (p. 389, italics added). However, for Simmel, there is never an equal reciprocity (as would be found in a tit-for-tat exchange): "the psychological situation makes it necessary for a gift received to be returned with a gift of an essentially different kind" (p. 390), one involving a "reaction equally to the benefit and to the benefactor" (p. 391).

Prior to Piaget, no one had written about how children or adolescents might come to distinguish between the obligations of contracts and those that come from within. Piaget, however, built on Kant's distinction to show how an autonomous feeling of obligation arises from children's peer relationships - that children come to accept for themselves the necessity to abide by rules they themselves have created in the course of their play (Freitas, 2003). This derives from mutual respect rather than from heteronomous respect for one's elders and betters whether a parent or God.

Piaget's (1932/1965) research on morality revealed that as children, in the preoperational stage, learn to feel unilateral respect (for parents, for God, for the predetermined and unchangeable rules of a game) they express a sense of heteronomous obligation. It is not that they always $d o$ the right thing (far from it), but when asked about what should be done, they are clear - one should do the right thing because parents or teachers or God or the rules say so. In the course of playing with peers, however, children, as they move from the preoperational to the concrete operational stage, come to a position of mutual respect - one should obey the rules of the game because the players have accepted this rule, and if they decide to change the rules that is fine, so long as all agree. Similarly, to behave morally is to do the good thing - which is not necessarily what parents or teachers say. Children may be no more likely to behave morally at this stage than they were when invoking heteronomous obligation, but their reasoning for behaving morally is quite different - the rules are to be followed because all have decided amongst themselves that they will be. In other words, the obligation (or duty) to play by the rules is freely decided and willingly enacted. It is this sort of autonomous sense of obligation that is essential for gratitude.

Interestingly, Piaget invoked the idea of reciprocity as being key to the development of autonomy. Just as unilateral respect goes hand in hand with heteronomy, so mutual respect and reciprocity relate to autonomy. "Autonomy therefore appears only with reciprocity, when mutual respect is strong enough to make the individual feel from within the desire to treat others as he himself would wish to be treated" (Piaget, 1932, p. 194, italics added). Piaget (1954/1981) thus wrote that gratitude "will be stabilized by the conservation of values and autonomous moral obligation" (p. 60).

Franziska Baumgarten-Tramer (1938), who seems to have been the first person to conduct research on the development of "gratefulness," defined it as a "reactive sentiment" to an act of kindness or assistance, and drew explicitly on Kant. She delineated four components: (a) happiness or joy at the received gift, help, or kindness, (b) saying "thank you" to the benefactor to indicate the pleasure received, (c) a "desire to render the helper a reciprocal service ... [which] develops spontaneously to please the person who has helped" (Baumgarten-Tramer, 1938 , p. 55), and (d) a sense that one has a moral obligation to repay the benefactor. She argued that gratitude goes beyond simple expression: “...thanks should not be 'empty,' that is to say, should not consist of words only but take some concrete form" (Baumgarten-Tramer, 1938, p. 55). Moreover, she specifically contrasted lawful obligations and debts of gratitude.

It is this distinction between feeling an obligation as an outside force and feeling it as something that one genuinely wants to fulfill that seems to be missing in much of the psychology or philosophy literature that objects to the 
idea that gratitude involves an obligation to reciprocate to one's benefactor. The language of duties and obligations, in relation to gratitude, does sound strange when one is only considering those duties and obligations that are externally imposed; those that come from within, autonomously, are central to understanding why people praise gratitude and excoriate ingratitude.

But if gratitude is more than a feeling and necessarily includes action - at least on occasions in which reciprocity is possible and reasonable - Baumgarten-Tramer's measure is still not enough as it only assesses what children and adolescents say they would do, not what they actually do. As Tudge, Freitas, and O'Brien (2015) argued, during childhood and adolescence a good deal of experience of gratitude and practice with gratitude is required before people are likely to become virtuous (see also Annas, 2011). What Baumgarten-Tramer's work (1938) suggests is that, with development, adolescents become increasingly likely to say that they would try to repay their benefactors with something of need or interest to those benefactors, and that without expressing this first at the verbal level one is unlikely to put that into practice. This also presupposes that children have developed a theory of mind (Nelson et al., 2013), that by middle childhood they have developed the ability to understand others' intentions (Jambon \& Smetana, 2014), and that in adolescence they have come to construct "a scale of values that also goes beyond the restricted circle of [their] immediate surroundings" (Piaget, 1965/1995, p. 299).

From a developmental point of view, it thus makes sense to expect young children at best to say "thank you" as the most limited form of verbal reciprocity. As children become a little older, and depending on their familial, school- and peer-based, and cultural experiences (Tudge et al., 2015) one might expect, as Baumgarten-Tramer (1938) found, the desire to reciprocate to a benefactor with something that the child, rather than the benefactor, would like. During the course of adolescence, however, this more egocentric type of reciprocity should give way to a type that takes the benefactor's wishes and desires into account. Combined with a move from a heteronomous to an autonomous sense of moral obligation, the seeds are thus sown for virtuous gratitude to flourish.

\section{Current Perspectives on and Definitions of Gratitude}

Leithart (2014) noted that gratitude has undergone a "revival" in recent years, particularly in the field of positive psychology. Nonetheless, he argued, current perspectives

What Is Gratitude? Ingratitude Provides the Answer of gratitude "...remain locked in a Lockean framework in which gratitude is a private sentiment or a matter of personal ethics, and is not a matter of serious philosophical or political concern" (p. 196). However, serious philosophical treatments of gratitude are not as rare as Leithart suggested (see, for example, Card, 1988; McAleer, 2012; Carr, 2013; Gulliford, Morgan, \& Kristjánsson, 2013; McConnell, 1993, 2016, 2017; Carr \& Harrison, 2018).

Nonetheless, contemporary discussions of gratitude have paid too little attention to the earlier distinction drawn between justice-related and affective-related senses of obligation (Aristotle, 350 BC/2018; Seneca, 54 AD/2011; Smith, 1759/2000; Kant, 1797/1964; Simmel, 1908/1950). However, to make sense of gratitude as a virtue this distinction between the heteronomous obligations of contracts involving justice and the autonomous obligations of respect, friendship, love, and gratitude has to be understood. The failure to distinguish them may have led Watkins (2014) to argue that gratitude had nothing to do with indebtedness or obligation. Carr (2013) distinguished gratitude as a moral virtue from both "obligation on the one hand [and] an attitude or mood of benign appreciation on the other" (p. 24). Card (1988) expressed the position as follows: "The idea of a debt of gratitude seems paradoxical. If that for which gratitude is due was neither for sale nor a mere loan but was in some sense gratis, what sense does it make to feel indebted for it?" (p. 115).

Card (1988) at least resolved the apparent paradox by describing obligations as being either formal or informal. As she argued, echoing the points made centuries earlier, the former are tied to justice - if we contract to do a piece of work and are paid for it, there is a legal obligation to do that work. Failure to do so puts us at the risk of being brought to justice. Having met our legal obligation, however, we are done; the contract has been met. Informal obligations are quite different; failure to meet the obligations of friendship or love (or gratitude) invokes no justice-related penalties, although moral condemnation may well follow, and the relationship is likely to be at risk. Paying off a formal debt means that it is discharged and both sides are happy; with informal obligation the opposite is true. Responding, with friendship, love, or gratitude to our friends, partners, or benefactors does anything but discharge or end the relationship - rather it strengthens it. Given gratitude's role in building and strengthening relationships, it becomes easy to see why ingratitude is viewed as morally loathsome. If a contract is not fulfilled, one can look for justice; there is no court that will adjudicate on the ungrateful individual. Instead, relationships between benefactors and beneficiaries are damaged or de- 
Table 1. Contrasts between "gratitude" definitions

\begin{tabular}{llllll}
\hline Definition & Benefactor & Benefit & Beneficiary & Reciprocation & Definition \\
\hline 2-part & $\mathrm{X}$ & $\mathrm{X}$ & $\mathrm{X}$ & & $\begin{array}{l}\text { appreciation } \\
\text { appreciation } \\
\text { 3-part }\end{array}$ \\
(or ingratitude) \\
4-part & $\mathrm{X}$ & $\mathrm{X}$ & $\mathrm{X}$ & $\mathrm{X}$ & X \\
\hline
\end{tabular}

In this chart, we are assuming that (a) the benefactor (if there is one) is intentionally trying to do something for the benefit of the beneficiary and that (b) the beneficiary feels something positive either towards the benefit, the benefactor, or both, (c) typically responds this way (that is, we cannot tell from a single response), and that (d), if there is reciprocation, it stems from a sense of obligation to reciprocate (autonomous rather than heteronomous).

stroyed by a habitual lack of reciprocity, just as a loving relationship is likely to fall apart, emotionally if not physically, if love becomes solely unidirectional. One is unlikely to stay friends with someone who never reciprocates in friendly ways.

Reciprocity is thus essential to gratitude, although it has been largely ignored in recent psychological research on gratitude. This is the case despite the fact that many researchers define the term using some version of Seneca's three-part notion of intentional benefactor, benefit, and beneficiary (Gulliford et al., 2013; Tudge et al., 2015; Navarro \& Morris, 2018). Or rather, to be more accurate, most constructs of gratitude found in the psychological literature can be categorized into one of three approaches: two-part, three-part, or four-part conceptions, of which the first two (separately or together) are the most common. The "parts" or subcomponents consist of four possible elements: (a) the beneficiary, (b) the benefit (or intended benefit), (c) the benefactor, and (d) reciprocation (or the intent to reciprocate). To illustrate the differences among these three approaches, consider the following example:

Claire is about to turn 12 and her close friends are coming over for a slumber party to celebrate. Knowing that Claire loves making crafts, her aunt Jennifer offers to come over with supplies and tools for Claire and her friends to make their own necklaces. Claire is thrilled and tells her friends about the activity planned for the slumber party. Jennifer lives a two-hour drive away from Claire's family, but really wants to do something special for her niece.

\section{Two-Part Gratitude}

One fairly common conceptualization of gratitude is as a positive emotion felt in response to receiving a benefit, or as a disposition to act gratefully (i.e., joyously or positively) when good things happen in life (Wood et al., 2008; McAleer, 2012; Vernon, 2012; Hoy, Suldo, \& Mendez, 2013; Jiang, Sun, Liu, \& Pan, 2016; Kwok, Gu, Tong, \& Kit, 2016; Johnson \& Wood, 2017; Bosacki, Sitnik, Dutcher, \& Talwar, 2018; Kwok, Gu, \& Cheung, 2019). For example, Johnson and Wood (2017) define gratitude as "the habitual noticing and appreciating the positive in the world" (p. 338). Using our "multilayer" analysis, this construct of gratitude is clearly comprised of two subcomponents: (a) the benefit and (b) the beneficiary (Table 1). To express two-part gratitude Claire (the beneficiary) might say: "I love all these crafting supplies. Making necklaces with my friends is so much fun!" Claire is clearly expressing joy and happiness from the benefit she received.

Such conceptualizations of gratitude have been found to be associated with life satisfaction, prosocial behaviors, and academic achievement (Froh, Sefick, \& Emmons, 2008; Froh, Bono, \& Emmons, 2010; Froh, Emmons, Card, Bono, \& Wilson, 2011a; Froh et al., 2011b; Bausert, Froh, Bono, Rose-Zornick, \& Rose, 2018). These highly positive outcomes are welcome news; we want our children and adolescents to be satisfied, prosocial, and work hard in school. But is this construct best described as gratitude, which should be a good in its own right and not an instrumental means to an end, no matter how good that end may be? Viewing gratitude solely as a positive emotion "runs the risk of sliding loosely into a conceptualization of gratitude that is uncritical and naively constructed" (Emmons, 2016a, p. 141). We agree with other scholars (e.g., Roberts, 2004; Carr, 2013; Gulliford et al., 2013; Fagley, 2016) who posit that there is a better construct to describe this good feeling - appreciation.

McAleer (2012) wrote in favor of two-part ("propositional") gratitude on the grounds that expressing grati-
Navarro/Tudge 
tude for what one has (irrespective of a human benefactor) relates to the virtue of humility. The development of humility is certainly desirable, particularly in the current context of rampant entitlement among youth (and adults). What distinguishes McAleer's two-part construct from that of others is the assumed motivation of the feeling. Rather than focusing on material gain (morally neutral or arguably morally deficient in the case of entitlement), McAleer's (2012) conceptualization of what he terms "gratitude" builds towards the virtue of humility through a "proper understanding of the place of humans in the natural world and a refusal to value nature merely instrumentally" (p. 63). Experiencing the beauty and power of lightning during a thunderstorm can inspire both awe and meekness, and perhaps even appreciation for the vastness and power of the natural world. And yet how would we treat friends who ran inside at the first sight of lightning? Would we castigate them as ungrateful? That seems highly unlikely. We might express a sense of disappointment at their lack of appreciation of something so awe-inspiring or sadness at their fear, but we would not call them ungrateful. We argue that this is because ingratitude is reserved for those who typically fail to reciprocate to their benefactors. While different in motivation from other conceptualizations of appreciation, McAleer's two-part gratitude is quite clearly that - appreciation.

\section{Three-Part Gratitude}

Most other scholars have embraced a three-part conceptualization of gratitude (e.g., Roberts, 2004; Carr, 2013; Gulliford et al., 2013; Kristjánsson, 2013; Fagley, 2016). Three-part gratitude has been described as a disposition to feel warmly about a benefactor. In this sense, gratitude is "a generalized tendency to recognize and respond with grateful emotion to the roles of other people's benevolence in the positive experiences and outcomes that one obtains" (McCullough, Emmons, \& Tsang, 2002, p. 112).

This three-part construct parallels two-part gratitude in that there is a benefit and the resulting good feeling on the part of the beneficiary, but adds acknowledgement of, and positive feeling toward, a benefactor. As such, threepart gratitude is comprised of: (a) a benefactor, (b) a benefit, and (c) a beneficiary (Table 1). This type of gratitude is directed to a benefactor, as opposed to gratitude for a benefit. As Roberts (2004) pointed out, the beneficiary must construe the actions of the benefactor to be intentional and benevolent: "What the grateful person cares

What Is Gratitude? Ingratitude Provides the Answer about is not solely the benefice as a good abstracted from the relationship with the benefactor; he may care just as much or more about the attitude of the benefactor namely, that he is benevolent toward him" (p. 62). Returning to our example, Claire might express three-part gratitude through a verbal appreciation of thanks towards her aunt: "I am so grateful to Aunt Jennifer for bringing all these supplies to my party." Many scholars accept this three-part approach as constituting gratitude. However, it seems to us that good feeling towards both the benefit and the benefactor may be necessary for gratitude but is not sufficient. After all, individuals' positive feeling towards their benefactors could simply be other-related appreciation, particularly in the absence of any opportunity to reciprocate. Assuming that there are opportunities to reciprocate - but these opportunities are never taken individuals are typically termed ungrateful rather than grateful (McConnell, 1993).

\section{Four-Part Gratitude}

Four-part gratitude adds an additional element - reciprocity. As a result, this construct is comprised of four elements, as shown in Table 1: (a) a benefactor, (b) a benefit, (c) a beneficiary, and (d) the latter's desire to reciprocate to the benefactor. We argue that this final element of reciprocity is essential to the definition of gratitude, just as lack of reciprocity defines ingratitude. As CompteSponville (2001) pointed out, for Kant (1797/1964) a purely affective (emotional) gratitude was simply benevolence; the act of reciprocity transformed it into the virtue of gratitude. Some scholars (Emmons \& Shelton, 2002; McCullough et al., 2002; Vaish \& Hepach, 2019) have claimed that feelings of benevolence might serve to motivate the beneficiary to wish to return the favor in some way. To the extent to which that motivation is accompanied, typically, by relevant action, we are dealing with four-part, or virtuous, gratitude.

In our example, Claire (at age 12) has likely developed the capacity to practice virtuous gratitude. Claire might respond to her aunt by initially giving verbal thanks (i.e., "I am so grateful to Aunt Jennifer") and then begin to think about a way to reciprocate in a way her aunt would appreciate. Knowing that Aunt Jennifer is moving to a new home in the near future, Claire might offer to come help her carry boxes on moving day. In turn, these reciprocal actions create an even closer connection between aunt and niece, spurring a cycle of reciprocity that strengthens their relationship across the life course. 
It is interesting to note that research (e.g., Bonnie \& de Waal, 2004) with chimps and capuchin monkeys revealed many examples of "true reciprocity" (noninstantaneous). Failure to reciprocate when it was deemed to be required by the previous benefactor's kind actions led to outpourings of what the authors referred to as "rage" directed against the prior beneficiary who had not behaved appropriately.

A recent analysis of 82 papers published since 2012, covering child and adolescent research into what the authors term gratitude, reveals that the most widely used definition is that of three-part gratitude (Navarro \& Tudge, 2020). Approximately $7 \%$ of definitions involved two-part gratitude, $36 \%$ used three-part gratitude, a further $15 \%$ used a definition that involved both two- and three-part gratitude (authors allowed either simple appreciation or a benefactor), and a further $21 \%$ involved four-part gratitude. The remaining papers either included no definition of the term at all (12\%) or simply described gratitude as a disposition or trait or referred to previous studies as the assumed source of their definition.

In point of fact, the situation is rather more complex than is shown in Table 1. A fuller description of four-part gratitude would include the following: (a) a benefactor who freely and intentionally provides (or attempts to provide), (b) a benefit to another, (c) a beneficiary who recognizes the benefit was given freely and with good intention and experiences a positive feeling, and, as a result, (d) freely wishes to repay the benefactor with something of value to the benefactor should a reasonable opportunity present itself. For example, gratitude may not be owed to those who, as Aristotle had noted $(350 \mathrm{BC} / 2018)$, are "constrained" or required to provide the benefit. It is also important, as Morgan and Gulliford (2018) pointed out, to understand the benefactor's intention in providing what might only appear to be a benefit, or when a benefit is given with clear expectation of some payback. Moreover, gratitude may be owed even in the absence of a benefit, as when a would-be benefactor tries very hard to provide a benefit but without success; the intention to provide a benefit might be sufficient (Gulliford, Morgan, Hemming, \& Abbott, 2019). Similarly, opportunities to reciprocate are not always available; as McConnell (1993) argued, people are only considered ungrateful if they typically fail to reciprocate to their benefactors when it would be possible to do so. Thus, the intention to reciprocate may be sufficient, rather than reciprocity itself, in those situations in which there is a lack of any reasonable opportunity to do so. When reciprocity does occur, it is also necessary to think about the original beneficiary's inten- tions. To be considered virtuously grateful, beneficiaries cannot reciprocate only under duress, they cannot do so in some tit-for-tat fashion, with no thought given to what might help or please the benefactor, or wishing merely to "pay off" their debt of gratitude as though it were some contract to be fulfilled. The wish to provide a benefit and the desire to reciprocate both need to be autonomous. To be sure, an autonomous desire to reciprocate does not necessarily signify gratitude - one can freely wish to settle one's contractual obligations. But people are not free to not settle the latter obligations. The "free wish" in the context of gratitude implies that one genuinely wants to do something kind or good for one's benefactor; it is this that is the mark of "genuine" or virtuous gratitude.

\section{The Measurement of What Is Termed Gratitude}

Despite this variety in the ways in which authors define gratitude, one measure (the Gratitude Questionnaire-Six: GQ-6, McCullough et al., 2002) seems to be the overwhelming choice. In 43 (52\%) of the papers examined by Navarro and Tudge (2020), it was the sole measure used, and in a further five (6\%) papers it was used in conjunction with either the Gratitude, Resentment, Appreciation Test short form (GRAT; Watkins et al., 2003) or the Gratitude Adjective Checklist (GAC; McCullough et al., 2002) or both. It makes sense for those authors who used a two- or three-part definition of gratitude to use these measures. For example, of the six items included in the GQ-6 three involve two-part gratitude (e.g., "I have so much in my life to be thankful for") and three may involve three-part gratitude (e.g., "Long amounts of time can go by before I feel grateful to something or someone," reverse coded). The same is true of the GRAT, whose subscales are (a) "sense of abundance," (b) "simple appreciation," and (c) appreciation for others. (The GAC asks respondents to indicate the extent to which they feel grateful, thankful, and appreciative.) Sure enough, five out of the six authors who used the two-part definition measured "gratitude" by one or more of these three scales, as did $70 \%$ of the 31 authors who used the threepart definition and $84 \%$ of the 13 who defined the term with a mixture of two- and three-part gratitude. However, it is interesting to note that of those who provided no definition at all $(n=10)$ or simply referred to the construct as a trait or disposition $(n=6)$, they were also likely to use the GQ-6 (50 and 71\%, respectively). In other words, the measure of gratitude has become associated with the GQ-6.
Navarro/Tudge 
To be sure, there are some scales that could be used to assess gratitude as a virtue among youth, but as yet they have been minimally used. For example, the Gratitude Assessment Questionnaire (Tudge \& Freitas, 2010) was designed to assess the extent to which respondents feel that they should reciprocate to those who have helped them or given them something and has good psychometric properties (Liang et al., under review) but it has only been used in two publications (Mendonça, Palhares, Tudge, \& Freitas, 2018; O’Brien et al., 2018). Similarly, Hussong and her colleagues (Hussong et al., 2019b; Hussong et al., 2020) have reported results using parents' reports of their "daily gratitude socialization behaviors" and their reports of their "child's daily gratitude" (Hussong et al., 2019a), as well as data from the Child Trends' Adolescent Gratitude Scale (Child Trends, 2013). However, most of the items on each of these scales fit better with appreciation than gratitude as a virtue (some items involve expressing thanks, others are about good manners, others are about the extent of privileges and possessions, and so on). They may all be good qualities for a child to have, but none of the items include the idea that there might be a moral obligation to reciprocate to those who have helped or given things. The same is true of the Multi-Component Gratitude Measure (Morgan, Gulliford, \& Kristjánsson, 2017), although this measure seems more designed for older adolescents and adults. There is a behavioral component that is tested, but the behavior assessed is simply the expression of thanks; admittedly, thanking behavior could be a precursor to reciprocity, but there is no necessity for that to occur, and it could be no more than a polite response (Freitas, Pieta, \& Tudge, 2011). Regardless, the GQ-6 remains overwhelmingly the instrument of choice for scholars intending to study gratitude.

Is that reasonable, or is it the case that the methodological tail is wagging the conceptual dog? As discussed earlier, scale items reflecting two-part gratitude (half the GQ-6 items) would be better defined as appreciation items. In the case of the GRAT (Watkins et al., 2003), which is treated as a measure of gratitude, the two most relevant subscales are both explicitly termed appreciation. Items include statements such as "Oftentimes I have been overwhelmed at the beauty of nature" and "I think it's important to enjoy the simple things of life" (both from the "Simple Appreciation" subscale). Items such as "I am grateful to a wide variety of people" (from the GQ6) or "I feel deeply appreciative of the things others have done for me in my life" (from the "Appreciation for Others" subscale) at least refer to other people, and so fit with

What Is Gratitude? Ingratitude Provides the Answer the three-part definition of gratitude. As Gulliford et al. (2013) wrote: "The two main instruments mix dyadic (generalized, or propositional) and triadic (targeted or prepositional) gratitude, despite the fact that the authors of the two papers in which these instruments are introduced define gratitude as a triadic concept" (p. 299). Of even more concern is the fact that none of the items from either of these scales reference any idea of reciprocity to those that have helped. One can feel "grateful" or "deeply appreciative" to others without ever attempting to reciprocate, and therefore be viewed as ungrateful rather than grateful. And if it is possible for a person to score high on one or other of these measures of gratitude and nonetheless be viewed as an ungrateful individual, there is surely something wrong with the measure.

Authors of 17 papers (21\% of the total) discussed gratitude using the four-part definition, involving reciprocation (Navarro \& Tudge, 2020). Of these papers, almost half $(47 \%)$ used the Wishes and Gratitude Survey (Freitas et al., 2008). This measure was an expanded version of Baumgarten-Tramer's (1938) measure and, as such, fits well with her position that gratitude necessarily involved reciprocation. A further $12 \%$ of the papers whose authors defined gratitude in this way used no measure at all, and the same percentage used the GQ-6. The remaining 29\% used one of various measures created by the authors themselves.

What this analysis reveals is the importance of taking seriously the issue of ingratitude in order to understand gratitude. Ingratitude, as discussed at the outset of this paper, is castigated as being morally suspect. But there is nothing immoral about failing to enjoy the falling leaves or the beautiful sunset, although people who do not enjoy them might well be thought of as unappreciative. It thus seems appropriate to view this two-part definition as relevant to appreciation rather than gratitude. It is not surprising that the two relevant subscales in the GRAT are both termed "appreciation" subscales. The three-part definition gets closer to what we consider to be gratitude, because at least this definition involves a benefactor to whom the beneficiary is said to be grateful (or appreciative). Although the GQ-6 uses the word "grateful" in two of the three items invoking other people (the remaining item uses "appreciative") the relevant subscale of the GRAT is termed "appreciation for others" although the word "thankful" is used in addition to appreciation. It seems reasonable to say that people who have warm feelings towards their benefactors should be considered to appreciate them; given that failure to reciprocate when it is possible to do so signifies ingratitude, people can be 
termed appreciative but ungrateful. It makes no sense to call them grateful but ungrateful.

Laypeople do not distinguish between being grateful, appreciative, and thankful, with "happy" also considered synonymous by some (Lambert, Fincham, Braithwaite, Graham, \& Beach, 2009; Morgan, Gulliford, \& Kristjánsson, 2014; Halberstadt et al., 2016; Ramsey, Gentzler, \& Vizy, 2018; Hussong et al., 2019a; Mendonça, 2019). Morgan et al. (2014), for example, found that grateful, appreciative, and thankful were the three central components of gratitude. Lambert et al. (2009) found that "happy feeling" was third most mentioned by their respondents, after appreciation and thankful and before grateful. It is thus not surprising that the GAC (McCullough et al., 2002) shows such high internal consistency (0.87) among the terms grateful, appreciative, and thankful when respondents are asked to describe themselves using a 9-point Likert scale ranging from inaccurate to accurate.

As developmental scientists, however, we need to be more precise in the language that we use. As Roberts (2004) argued, "if we are going to have a science of something, we had better have a pretty clear idea what that thing is and be careful not to confuse it with other things that are a little bit like it" (p. 65). Gulliford et al. (2013) made a similar claim about the lack of conceptual clarity shown by many psychologists who have taken to studying what they term gratitude.

This is why it helps to consider ingratitude to help distinguish among these terms and, as we have made clear, ingratitude most aptly applies to people who consistently fail to willingly reciprocate to their benefactors. We have argued that ingratitude is the opposite of gratitude, but not of appreciation or happiness. An alternative claim has been put forward by Johnson and Wood (2017), who argued that "gratitude is continuous with ingratitude" (p. 337), merely the end points on a single continuum. From their point of view, the lower an individual scores on the GQ-6, GRAT, or GAC the more ungrateful they are. We, however, are at a loss to understand why disagreeing with statements such as "I have so much in my life to be thankful for," "I am grateful to a wide variety of people" (both from the GQ-6), "Life has been good to me," or "I think it's important to "Stop and smell the roses"' (from the GRAT) have anything to do with ingratitude, given that this term seems to be reserved for something morally reprehensible. If gratitude is defined as a virtue, and ingratitude is, therefore, a vice, these scales should not be used to assess gratitude as a virtue. However, because they are termed "gratitude" scales they are treated as though they measure gratitude. From the point of view of developmental science, it should be the conceptual dog that takes the lead role and not the operational tail.

\section{Conclusion}

When considered as a virtue, gratitude is a complex construct. Very young children can be taught to say "thank you," and many parents around the world work hard to ensure that they do not appear rude to their benefactors (Visser, 2009). Children are also likely to feel a positive emotion when getting something they want. But gratitude involves so much more than offering thanks or feeling good; it includes having a theory of mind (Nelson et al., 2013), an understanding of intentionality, the development of an autonomous sense of moral obligation, and a good deal more (see McConnell, 1993). Aristotle is again helpful, with his notion of phronesis (practical wisdom). Children have to learn not only the conditions under which gratitude is owed, but what counts as appropriate gratitude and what counts as the marker of a grateful person. For example, they need to understand that any failure to act gratefully is not sufficient for a person to be considered ungrateful, just as a solitary response that indicates gratitude is unlikely to be treated as evidence that the responder is a grateful person. One can also appear to be overly grateful (obsequious), if every slight favor or good turn is treated as though the recipient's greatest wishes had just been fulfilled. As Carr et al. (2015) noted, we have to learn to not be "ungrateful when we ought not to be, or mistakenly grateful where such gratitude is not warranted" (p. 775).

All of this takes time to develop (Annas, 2011; Tudge et al., 2015), which explains why a number of scholars have found clear patterns of the expression of different types of gratitude across childhood and adolescence. Across different societies, 14- to 15-year-old adolescents are far more likely than those who are younger to at least say that one should reciprocate to one's benefactors with something of interest to them (Baumgarten-Tramer, 1938; Freitas et al., 2011; Mendonça, Merçon-Vargas, Payir, \& Tudge, 2018; Payir et al., 2018). Adolescents, similarly, are more likely than younger children to say that their beneficiaries have a moral obligation to help their benefactors (Castro, Rava, Hoefelmann, Pieta, \& Freitas, 2011; Mendonça et al., 2018).

To the extent that a person typically responds appropriately to someone who has provided benefits and who looks for opportunities to reciprocate - or at least takes 
those opportunities when they are presented - in some way that would please that benefactor, he or she is likely to be considered a grateful person. And to the extent to which people typically do not respond in those ways, even when there is an opportunity to do so, they are castigated as being ungrateful. If the person is a child, however, failure to respond gratefully is to be expected; but it is also hoped that, over time, the child will learn to become grateful.

However, time alone is unlikely to be sufficient for the development of gratitude, and both the cultural community in which one is raised and the help and encouragement of teachers and parents are necessary (Tudge et al., 2015). As Morgan, Gulliford, and Carr (2015) pointed out: "To take gratitude to be of moral concern is surely to conceive it as a quality or capacity that deserves cultivation for the individual or common good" (p. 98). Carr (2013) went further: "Virtuous gratitude can and should be taught - and, we might hope, is the daily pedagogical fare of all parental, educational and other benefactors who appreciate the central human value of such a virtue" (p. 28). This surely means more than simply encouraging children to say "thank you" when receiving help or a gift, appreciating the world around them, or engaging in interventions that seem to have purely instrumental benefits. It is also important to encourage the autonomous sense of moral obligation to reciprocate. It is perhaps the focus on contracts and justice that lead some children and adolescents to feel a sense of entitlement - parents and teachers may be viewed as being required to provide for and help children, and so gratitude is not needed. Similarly, if people feel that the world is there to satisfy all our wants there need be no feeling that one also has a duty to care for the planet. We do have obligations, but they are not of the contractual type, but need to come from an autonomous moral sense that they are the right thing to enact. Carr and Harrison (2018) have shown how literature can be used to help children understand gratitude considered in this way. There is also evidence that interventions designed to encourage the expression of virtuous grati- tude are effective during adolescence (Mendonça, Navarro, Navarro, \& Tudge, 2019; Navarro, Mendonça, Li, \& Tudge, 2019).

If we want to encourage grateful behavior in our children (through discussions or interventions in homes, schools, and the wider community) we must make deliberate choices about what construct of gratitude we want to encourage. To clarify this imperative, engage in a simple thought experiment to imagine the opposite - how can we encourage our children NOT to be ungrateful? As gratitude's opposite, ingratitude "....is the failure to both acknowledge receiving a favor and refusing to return or repay the favor" (Emmons, 2016a, p. 147). We argue that by aiming for this goal - raising children NOT to have the vice of ingratitude - we can go beyond merely encouraging appreciation or saying "thank you," we can encourage the development of gratitude as a virtue. Let's aim high (well, at least as high as our reciprocating primate cousins)!

\section{Acknowledgment}

Thank you very much to Lia B.L. Freitas for her support and feedback on this paper.

\section{Statement of Ethics}

As this paper is theoretical in nature, no ethical approval was required.

\section{Disclosure Statement}

The authors have no conflicts of interest to declare.

\section{Author Contributions}

The authors contributed equally to the writing of this paper.

\section{References}

What Is Gratitude? Ingratitude Provides the Answer
Adler, M. G., \& Fagley, N. S. (2005). Appreciation: Individual differences in finding value and meaning as a unique predictor of subjective well-being. Journal of Personality, 73(1), 79114. https://doi.org/10.1111/j.1467-6494.2004. 00305.x

Annas, J. (2011). Intelligent virtue. Oxford, UK: Oxford University Press. https://doi. org/10.1093/acprof:oso/9780199228782. 001.0001
Aristotle (2014). Nichomachean ethics (R. Crisp, Trans., original work written in the fourth century BC). Cambridge, UK: Cambridge University Press.

Aristotle (2018). Rhetoric (C. D. C. Reeve, Trans., original work written in approximately 350 BC). Indianapolis, IN: Hackett Publishing. 
Baumgarten-Tramer, F. (1938). "Gratefulness" in children and young people. The Pedagogical Seminary and Journal of Genetic Psychology, 53(1), 53-66. https://doi.org/10.1080/088565 59.1938.10533797

Bausert, S., Froh, J. J., Bono, G., Rose-Zornick, R., \& Rose, Z. (2018). Gratitude in adolescence: Determinants and effects on development, prosocial behavior, and well-being. In J. R. H. Tudge \& L. B. L. Freitas (Eds.), Developing gratitude in children and adolescents (pp. 135-153). Cambridge, UK: Cambridge University Press.

Bonnie, K. E., \& de Waal, F. B. (2004). Primate social reciprocity and the origin of gratitude. In R. A. Emmons \& M. E. McCullough (Eds.), The psychology of gratitude (pp. 213-235). Oxford, UK: Oxford University Press. https:// doi.org/10.1093/acprof:oso/9780195150100. 003.0011

Bosacki, S., Sitnik, V., Dutcher, K., \& Talwar, V. (2018). Gratitude, social cognition, and wellbeing in emerging adolescents. The Journal of Genetic Psychology, 179(5), 256-269. https:// doi.org/10.1080/00221325.2018.1499607

Brown, P. (2012). Through the eye of a needle: Wealth, the fall of Rome, and the making of Christianity in the west, 350-550 AD. Princeton, NJ: Princeton University Press.

Card, C. (1988). Gratitude and obligation. American Philosophical Quarterly, 25(2), 115-127.

Carr, D. (2013). Varieties of gratitude. The Journal of Value Inquiry, 47(1-2), 17-28. https:// doi.org/10.1007/s10790-013-9364-2

Carr, D. (2016). (Ed.) Perspectives on gratitude: An interdisciplinary approach. London, UK: Routledge.

Carr, D., \& Harrison, T. (2018). Teaching gratitude through literature. In J. R. H. Tudge \& L. B. L. Freitas (Eds.), Developing gratitude in children and adolescents (pp. 262-282). Cambridge, UK: Cambridge University Press.

Carr, D., Morgan, B., \& Gulliford, L. (2015). Learning and teaching virtuous gratitude. $O x$ ford Review of Education, 41(6), 766-781. https://doi.org/10.1080/03054985.2015.1119 679

Castro, F. M. P., Rava, P. G. S., Hoefelmann, T. B., Pieta, M. A. M., \& Freitas, L. B. L. (2011). Should one return a favor? Gratitude and symbolic debt in childhood. Estudos de Psicologia, 16, 75-82. https://doi.org/10.1590/ S1413-294X2011000100010

Child Trends. (2013). Positive Indicators Project. Retrieved from https://www.childtrends.org/ research/research-by-topic/positive-indicators-project/gratitude/

Comte-Sponville, A. (2002). A small treatise on the great virtues: The uses of philosophy in everyday life (first published in French in 1996). New York, NY: Holt \& Co.

Cureton, A., \& Hill, T. E. (2015). Kant on virtue and the virtues. In N. E. Snow (Ed.), Cultivating virtue: Perspectives from philosophy, theology, and psychology (pp. 87-109). Oxford, UK: Oxford University Press.
Dunn, C. (1946). The concept of ingratitude in Renaissance English moral philosophy. Washington, DC: Catholic University of America Press.

Emmons, R. A. (2004). The psychology of gratitude: An introduction. In R. A. Emmons \& M. E. McCullough (Eds.), The psychology of gratitude (pp. 3-16). Series in affective science. Oxford, UK: Oxford University Press. https:// doi.org/10.1093/acprof:oso/9780195150100. 003.0001

Emmons, R. A. (2007). Thanks! How practicing gratitude can make you happy. Boston, MA: Houghton Mifflin.

Emmons, R. A. (2009). Greatest of the virtues? Gratitude and the grateful personality. In D. Narvaez \& D. Lapsley (Eds.), Personality, identity, and character: Explorations in moral psychology (pp. 256-270). Cambridge, UK: Cambridge University Press. https://doi. org/10.1017/CBO9780511627125.012

Emmons, R. A. (2013). Gratitude works! A 21-day program for creating emotional prosperity. San Francisco, CA: Jossey-Bass.

Emmons, R. A. (2016a). Is gratitude queen of the virtues and ingratitude king of the vices? In D. Carr (Ed.), Perspectives on gratitude: An interdisciplinary approach (pp. 141-153). London, UK: Routledge.

Emmons, R. A. (2016b). The little book of gratitude. London, UK: Gaia Books.

Emmons, R. A., \& Crumpler, C. A. (2000). Gratitude as a human strength: Appraising the evidence. Journal of Social and Clinical Psychology, 19(1), 56-69. https://doi.org/10.1521/ jscp.2000.19.1.56

Emmons, R. A., \& McCullough, M. E. (Eds.). (2004). The psychology of gratitude. Oxford, UK: Oxford University Press. https://doi. org/10.1093/acprof:oso/9780195150100. 001.0001

Emmons, R. A., \& Shelton, C. M. (2002). Gratitude and the science of positive psychology. Handbook of Positive Psychology, 18, 459471.

Fagley, N. S. (2016). The construct of appreciation: It is so much more than gratitude. In D. Carr (Ed.), Perspectives on gratitude: An interdisciplinary approach (pp. 70-84). London, UK: Routledge.

Freitas, L. B. D. L., Pieta, M. A. M., \& Tudge, J. R. H. (2011). Beyond politeness: The expression of gratitude in children and adolescents. Psicologia: Reflexão e Crítica, 24(4), 757-764. https:// doi.org/10.1590/S0102-79722011000400016

Freitas, L. B. L. (2003). A moral na obra de Jean Piaget: Um projeto inacabado [The theory of morality in Jean Piaget's work: An unfinished project]. São Paulo, Brazil: Cortez.

Freitas, L. B. L., Tudge, J. R. H., \& McConnell, T. (2008). The wishes and gratitude survey. Greensboro, NC: Unpublished questionnaire. (Adapted and expanded from BaumgartenTramer, 1938).

Froh, J. J., \& Bono, G. (2014). Making grateful kids: The science of building character. Conshohocken, PA: Templeton Press.
Froh, J. J., Bono, G., \& Emmons, R. (2010). Being grateful is beyond good manners: Gratitude and motivation to contribute to society among early adolescents. Motivation and Emotion, 34(2), 144-157. https://doi. org/10.1007/s11031-010-9163-z

Froh, J. J., Emmons, R. A., Card, N. A., Bono, G., \& Wilson, J. A. (2011a). Gratitude and the reduced costs of materialism in adolescents. Journal of Happiness Studies, 12(2), 289-302. https://doi.org/10.1007/s10902-010-9195-9

Froh, J. J., Fan, J., Emmons, R. A., Bono, G., Huebner, E. S., \& Watkins, P. (2011b). Measuring gratitude in youth: Assessing the psychometric properties of adult gratitude scales in children and adolescents. Psychological Assessment, 23(2),311-324.https://doi.org/10.1037/ a0021590

Froh, J. J., Sefick, W. J., \& Emmons, R. A. (2008). Counting blessings in early adolescents: An experimental study of gratitude and subjective well-being. Journal of School Psychology, 46(2), 213-233. https://doi.org/10.1016/j. jsp.2007.03.005

Gulliford, L., Morgan, B., Hemming, E., \& Abbott, J. (2019). Gratitude, self-monitoring, and social intelligence: A prosocial relationship? Current Psychology (New Brunswick, N.J.), 38(4), 1021-1032. https://doi. org/10.1007/s12144-019-00330-w

Gulliford, L., Morgan, B., \& Kristjánsson, K. (2013). Recent work on the concept of gratitude in philosophy and psychology. The Journal of Value Inquiry, 47(3), 285-317. https:// doi.org/10.1007/s10790-013-9387-8

Halberstadt, A. G., Langley, H. A., Hussong, A. M., Rothenberg, W. A., Coffman, J. L., Mokrova, I. L., \& Costanzo, P. R. (2016). Parents' understanding of gratitude in children: A thematic analysis. Early Childhood Research Quarterly, 36, 439-451. https://doi. org/10.1016/j.ecresq.2016.01.014

Hobbes, T. (2018). Leviathan (first published in 1651). Minneapolis, MN: Lerner Publishing.

Hoy, B. D., Suldo, S. M., \& Mendez, L. R. (2013). Links between parents' and children's levels of gratitude, life satisfaction, and hope. Journal of Happiness Studies, 14(4), 1343-1361. https://doi.org/10.1007/s10902-012-9386-7

Hussong, A. M., Coffman, J. L., \& Thomas, T. E. (2020). Gratitude conversations: An experimental trial of an online parenting tool. The Journal of Positive Psychology, 15(2), 267-277. doi: 10.1080/17439760.2019.1610484

Hussong, A. M., Langley, H. A., Rothenberg, W. A., Coffman, J. L., Halberstadt, A. G., Costanzo, P. R., \& Mokrova, I. (2019a). Raising grateful children one day at a time. Applied Developmental Science, 23(4), 371-384. https://doi. org/10.1080/10888691.2018.1441713

Hussong, A. M., Langley, H. A., Thomas, T., Coffman, J., Halberstadt, A., Costanzo, P., \& Rothenberg, W. A. (2019b). Measuring gratitude in children. The Journal of Positive Psychology, 14(5), 563-575. https://doi.org/10.10 80/17439760.2018.1497692 
Jambon, M., \& Smetana, J. G. (2014). Moral complexity in middle childhood: Children's evaluations of necessary harm. Developmental Psychology, 50(1), 22-33. https://doi. org/10.1037/a0032992

Jiang, H., Sun, P., Liu, Y., \& Pan, M. (2016). Gratitude and late adolescents' school well-being: The mediating role of materialism. Social Indicators Research, 127(3), 1363-1376. https:// doi.org/10.1007/s11205-015-1007-5

Johnson, J., \& Wood, A. (2017). Integrating positive and clinical psychology: Viewing human functioning as continua from positive to negative can benefit clinical assessment, interventions and understandings of resilience. Cognitive Therapy and Research, 41(3), 335349. https://doi.org/10.1007/s10608-0159728-y

Kant, I. (1964). The doctrine of virtue (first published in 1797). New York, NY: Harper \& Row.

Konstan, D. (2016). The freedom to feel grateful: The view from classical antiquity. In D. Carr (Ed.), Perspectives on gratitude: An interdisciplinary approach (pp. 41-53). London, UK: Routledge.

Kristjánsson, K. (2007). Aristotle, emotions, and education. London, UK: Routledge.

Kristjánsson, K. (2013). Virtues and vices in positive psychology. Cambridge, UK: Cambridge University Press. https://doi.org/10.1017/ CBO9781139177818

Kwok, S. Y. C. L., Gu, M., \& Cheung, A. (2019). A longitudinal study on the relationship among childhood emotional abuse, gratitude, and suicidal ideation of Chinese adolescents. Child Abuse \& Neglect, 94, 104031. https:// doi.org/10.1016/j.chiabu.2019.104031

Kwok, S. Y. C. L., Gu, M., Tong, K., \& Kit, K. (2016). Positive psychology intervention to alleviate child depression and increase life satisfaction: A randomized clinical trial. Research on Social Work Practice, 26(4), 350-361. https://doi.org/10.1177/1049731516629799

Lambert, N. M., Fincham, F. D., Braithwaite, S. R., Graham, S. M., \& Beach, S. R. (2009). Can prayer increase gratitude? Psychology of Religion and Spirituality, 1(3), 139-149. https:// doi.org/10.1037/a0016731

Leithart, P. J. (2014). Gratitude: an intellectual history. Waco, TX: Baylor University Press.

Liang, Y., Tudge, J. R. H., Freitas, L. B. L., Chen, Y., Zhou, N., \& Cao, H. (under review). Gratitude as a moral virtue: A psychometric evaluation of the gratitude assessment questionnaire (GAQ), the role of parental socialization, and associations with socio-emotional adjustment in Chinese youth. Applied Developmental Science.

Locke, J. (1690). An essay concerning human understanding. Retrieved from http://www. pinkmonkey.com/dl/library1/book1284.pdf https://doi.org/10.1093/oseo/instance. 00018020

McAleer, S. (2012). Propositional gratitude. American Philosophical Quarterly, 49(1), 5566.
McConnell, T. (1993). Gratitude. Philadelphia, PA: Temple University Press.

McConnell, T. (2016). Gratitude's value. In D. Carr (Ed.), Perspectives on gratitude: An interdisciplinary approach (pp. 27-40). London, UK: Routledge.

McConnell, T. (2017). Gratitude, rights, and moral standouts. Ethical Theory and Moral Practice, 20(2), 279-293. https://doi.org/10.1007/ s10677-016-9761-2

McCullough, M. E., Emmons, R. A., \& Tsang, J. A. (2002). The grateful disposition: A conceptual and empirical topography. Journal of Personality and Social Psychology, 82(1), 112127.https://doi.org/10.1037/0022-3514.82. 1.112

Mendonça, S. E. (2019). A grateful heart: Parents' reflection on gratitude and its development in their children (unpublished doctoral dissertation), The University of North Carolina at Greensboro, NC.

Mendonça, S. E., Merçon-Vargas, E. A., Payir, A., \& Tudge, J. R. H. (2018). The development of gratitude in seven societies: Cross-cultural highlights. Cross-Cultural Research, 52(1), 135-150. 1069397117737245

Mendonça, S. E., Navarro, K., Navarro, J., \& Tudge, J. R. H. (2019). A culture of character? Virtuous gratitude in a Montessori setting. Poster presented at the Association of Moral Education annual meeting, Seattle, WA.

Mendonça, S. E., Palhares, F., Tudge, J. R. H., \& Freitas, L. B. L. (2018). Gratitude and moral obligation. In J. R. H. Tudge \& L. B. L. Freitas (Eds.), Developing gratitude in children and adolescents (pp. 89-110). Cambridge, UK: Cambridge University Press.

Morgan, B., \& Gulliford, L. (2018). Assessing influence on gratitude experience: Age-related differences in how gratitude is understood and experienced. In J. R. H. Tudge \& L. B. L. Freitas (Eds.), Developing gratitude in children and adolescents (pp. 65-88). Cambridge, UK: Cambridge University Press.

Morgan, B., Gulliford, L., \& Carr, D. (2015). Educating gratitude: Some conceptual and moral misgivings. Journal of Moral Education, 44(1), 97-111. https://doi.org/10.1080/03057 240.2014.1002461

Morgan, B., Gulliford, L., \& Kristjánsson, K. (2014). Gratitude in the UK: A new prototype analysis and a cross-cultural comparison. The Journal of Positive Psychology, 9(4), 281-294. https://doi.org/10.1080/17439760.2014.8983 21

Morgan, B., Gulliford, L., \& Kristjánsson, K. (2017). A new approach to measuring moral virtues: The multi-component gratitude measure. Personality and Individual Differences, 107, 179-189. https://doi.org/10.1016/j. paid.2016.11.044
Navarro, J. L., Mendonça, S. E., Li, R., \& Tudge, J. R. H. (2019). The cultivation of gratitude in school in the United States. Presented as part of a symposium, "Gratitude in youth and adults in the United States, Brazil, and Poland" (J. Tudge \& L. Freitas, Chairs) at the biennial meetings of the Society for Research in Child Development, Baltimore, MD.

Navarro, J. L., \& Morris, H. (2018, October). Defining gratitude: A theoretical and methodological review of research with children and adolescents. Poster presentation at SRCD Character Development Special Topic Meeting, Philadelphia, PA.

Navarro, J. L. \& Tudge, J. R. H. (2020). Defining gratitude: A conceptual and methodological analysis. In preparation.

Nelson, J. A., de Lucca Freitas, L. B., O’Brien, M., Calkins, S. D., Leerkes, E. M., \& Marcovitch, S. (2013). Preschool-aged children's understanding of gratitude: Relations with emotion and mental state knowledge. British Journal of Developmental Psychology, 31(Pt 1), 42-56. https://doi.org/10.1111/j.2044-835X. 2012.02077.x

O'Brien, L., Liang, Y., Merçon-Vargas, E. A., Price, U. S., \& Leon, E. D. (2018). Relations between parents' and children's gratitude. In J. R. H. Tudge \& L. B. L. Freitas (Eds.), Developing gratitude in children and adolescents (pp. 177-198). Cambridge, UK: Cambridge University Press.

Payir, A., Mendonça, S. E., Liang, Y., Mokrova, I., Palhares, F., \& Zeytinoglu, S. (2018). Crosscultural variations in the development of gratitude. In J. R. H. Tudge \& L. B. L. Freitas (Eds.), Developing gratitude in children and adolescents (pp. 111-134). Cambridge, UK: Cambridge University Press.

Piaget, J. (1932). The moral judgement of the child. New York, NY: Harcourt Brace.

Piaget, J. (1981). Intelligence and affectivity: Their relationship during child development (original work published 1954). Annual Reviews. Washington, DC: American Psychological Association.

Piaget, J. (1995). Sociological studies (original work published 1928). New York, NY: Routledge.

Ramsey, M. A., Gentzler, A. L., \& Vizy, B. (2018). Children's and parents' understanding of gratitude. In J. R. H. Tudge \& L. B. L. Freitas (Eds.), Developing gratitude in children and adolescents (pp. 220-239). Cambridge, UK: Cambridge University Press.

Roberts, R. C. (2004). The blessings of gratitude: A conceptual analysis. In R. A. Emmons \& M. E. McCullough (Eds.), The psychology of gratitude (pp. 58-78). Oxford, UK: Oxford University Press. https://doi.org/10.1093/acprof: oso/9780195150100.003.0004

Seneca, L. A. (2011). On benefits (first published in 54 AD). Chicago, IL: University of Chicago Press.

Simmel, G. (1950). Faithfulness and gratitude (first published in 1908). In K. H. Wolff (Ed.), The sociology of Georg Simmel (pp. 379-395). New York, NY: The Free Press. 
Smith, A. (2000). The theory of moral sentiments (first published in 1759). New York, NY: Prometheus.

Tudge, J. R. H., \& Freitas, L. B. L. (2010). Gratitude Assessment Questionnaire. Unpublished scale. The University of North Carolina at Greensboro

Tudge, J. R. H., \& Freitas, L. B. L. (Eds.) (2018). Developing gratitude in children and adolescents. Cambridge, UK: Cambridge University Press.

Tudge, J. R. H., Freitas, L. B. L., \& O’Brien, L. T. (2015). The virtue of gratitude: A developmental and cultural approach. Human Development, 58(4-5), 281-300. https://doi. org $/ 10.1159 / 000444308$

Vaisch, A., \& Hepach, R. (2019). The development of prosocial emotions. Emotion Review, https://doi.org/10.1177/1754073919885014
Vernon, L. L. (2012). Relationships among proactive coping, posttrauma gratitude, and psychopathology in a traumatized college sample. Journal of Aggression, Maltreatment \& Trauma, 21(1), 114-130. https://doi.org/10.1 080/10926771.2012.633298

Visser, M. (2009). The gift of thanks: The roots and rituals of gratitude. New York, NY: Harper Collins.

Watkins, P. C. (2014). Gratitude and the good life: Toward a psychology of appreciation. Berlin, Germany: Springer. https://doi.org/10.1007/ 978-94-007-7253-3

Watkins, P. C., Grimm, D. L., \& Kolts, R. (2004). Counting your blessings: Positive memories among grateful persons. Current Psychology (New Brunswick, N.J.), 23(1), 52-67. https:// doi.org/10.1007/s12144-004-1008-z
Watkins, P. C., Woodward, K., Stone, T., \& Kolts, R. L. (2003). Gratitude and happiness: Development of a measure of gratitude, and relationships with subjective wellbeing. Social Behavior and Personality, 31(5), 431-452. https://doi.org/10.2224/sbp.2003.31.5.431

Winter, B. W. (1988). The public honoring of Christian benefactors: Romans 13.3-4 and 1 Peter 1.14-15. Journal for the Study of the New Testament, 34, 87-103. https://doi.org/ 10.1177/0142064X8801103406

Wood, A. M., Froh, J. J., \& Geraghty, A. W. A (2010). Gratitude and well-being: A review and theoretical integration. Clinical Psychology Review, 30(7), 890-905. https://doi. org/10.1016/j.cpr.2010.03.005

Wood, A. M., Maltby, J., Gillett, R., Linley, P. A. \& Joseph, S. (2008). The role of gratitude in the development of social support, stress, and depression: Two longitudinal studies. Journal of Research in Personality, 42(4), 854-871. https://doi.org/10.1016/j.jrp.2007.11.003 